\title{
DA PROPAGANDA À "PUBLICIDADE" POLÍTICA: A IDEIA DE CONSUMO E DESCARTE NA CAMPANHA ELEITORAL DE HADDAD
}

\section{Advertisement to "publicity" politics: the idea of consumption and dis posal in electoral campaign of Haddad}

\section{Del anuncio a la "publicidad" política: la idea de Consumo y eliminación en la campaña electoral de haddad}

Diógenes José Pasqualini ${ }^{1}$

“O novo não está no que é dito, mas no acontecimento de sua volta.” (FOUCAULT, 2001:26)

\section{Resumo}

O presente texto tem por objetivo observar semelhanças entre os slogans de posicionamento das campanhas do candidato a prefeito de São Paulo Fernando Haddad (PT), em 2012, e os da Ford, na promoção da marca em 2006 e lançamento do novo Fiesta em 2007, e a análise do consumo observada pelo filósofo francês Gilles Lipovetsky (1996, 2005, 2007). O que se busca analisar aqui é a identificação da propaganda política com os discursos publicitários no desencadeamento do efeito cíclico entre desejo, consumo e posterior "descarte" do político.

Palavras-chave: eleição 2012, Fernando Haddad, marketing político, discurso publicitário, consumo.

\footnotetext{
Abstract

This paper aims to observe likeness between the slogans positioning campaigns the candidate for mayor of São Paulo Fernando Haddad (PT), in 2012, and Ford's, in promoting the brand in 2006 and Ford, in promoting the brand in 2006 and launching of the new Fiesta in 2007, and the analysis of consumption observed by French

${ }^{1}$ Doutorando em Comunicação e Semiótica pela Pontifícia Universidade Católica de São Paulo - PUCSP. Endereço para correspondência: Rua 21, n 118 - Avs. 25 e 27 - CEP 13.503-380 - Estádio - Rio Claro - SP. E-mail: didibr@estadao.com.br.
} 
Da propaganda à "publicidade" política: a ideia de consumo e descarte na campanha eleitoral de Haddad

de Diógenes José Pasqualini

philosopher Gilles Lipovetsky $(1996,2005,2007)$. What is sought here is to analyze the identification of political propaganda with speeches advertising on triggering the cyclical effect between desire, consumption and subsequent "dispose" of politics.

Keywords: 2012 election, Fernando Haddad, political marketing, advertising discourse, consumption.

\section{Resumen}

Este trabajo tiene como objetivo observar las similitudes entre los slogans de posicionamiento del candidato a la alcaldía de São Paulo Fernando Haddad (EN), en 2012 , las campañas de Ford, en la promoción de la marca en 2006 y el lanzamiento del nuevo Fiesta en 2007 y el análisis del consumo observado por el filósofo francés Gilles Lipovetsky (1996, 2005, 2007 ) . Lo que se busca aquí es analizar la identificación de la publicidad política con la publicidad en el desencadenamiento de efecto cíclico entre el deseo , el consumo y la posterior "disponer " del discurso político .

Palabras-clave: elección 2012, Fernando Haddad, el marketing político, el discurso publicitario, el consumo.

\section{INTRODUÇÃO}

A proposta da qual aqui se parte é a de observar se os discursos da propaganda política estão se tornando cada vez mais parecidos com os da publicidade, como eles atuam e relacionam as regras de consumo com a escolha do candidato. Nos últimos anos, tem-se percebido que o marketing político, em se tratando de estratégia de comunicação, está cada vez mais parecido com as técnicas de venda de mercadorias. Em São Paulo, os três candidatos ${ }^{2}$ mais bem votados para o cargo de prefeito exploraram bem esta técnica no primeiro turno das eleições municipais de 2012.

As promessas seguiram a linha de apresentação dos benefícios de um produto, ancoradas à marca símbolo em que se transformaram os partidos políticos. O que se pretende discutir aqui não é se esta "tendência" é ou não correta, do ponto de vista da

\footnotetext{
${ }^{2}$ Concorreram às eleições Majoritárias em São Paulo em 2012, 12 candidatos - José Serra, Celso Russomanno, Fernando Haddad, Gabriel Chalita, Soninha, Carlos Giannazi, Paulinho da Força, Levy Fidelix, Ana Luisa, Miguel, Eymael e Anaí Caproni. Disputaram o segundo turno José Serra e Fernando Haddad, eleito prefeito com $55,5 \%$ dos votos válidos.
} 
Da propaganda à "publicidade" política: a ideia de consumo e descarte na campanha eleitoral de Haddad

de Diógenes José Pasqualini

promoção, se rende ou não votos ou se aumenta ou reduz a chance deste ou daquele candidato, mas a relação que a sociedade passa a ter com bens de consumo e as candidaturas e se esta mudança tem impacto no interesse/desinteresse pelo voto.

Gilles Lipovetsky (1996, 2005, 2007), em suas reflexões sobre comunicação, consumo, moda e seus efeitos sobre a sociedade, nos diz que a experiência do consumo é marcada por várias etapas e está ligada ao desenvolvimento industrial, à comunicação, à cultura de produção, ao individualismo e à diferenciação. A forte adesão das sociedades ao consumo, nas últimas décadas, atingiu patamares que forçaram a nova denominação de era do "hiperconsumo".

Segundo Lipovetsky, o consumo vem, ao longo das décadas pós-segunda guerra, ocupando cada vez mais um lugar de destaque na vida das pessoas e faz parte de uma ideia de modernidade, desenvolvimento, progresso e liberdade. E também sugere distinção entre as pessoas ao promover a individualidade e a sensação de liberdade. Para ele, o marketing e a publicidade atuam como os promotores do consumo, pois segmentam mercados, desenvolvem estratégias de venda, usam ferramentas para pesquisar as necessidades do cliente, fidelizam mercados, despertam uma cultura marcada pela oferta de produtos e buscam na própria fidelidade a infidelidade, que passa a ser o "resíduo" que permanece na busca por novos clientes. O consumidor passa a ser tratado como "rei" em troca da "fidelidade" que realimenta o consumo e a manutenção das marcas.

É na individualização que o marketing consegue penetrar com mais proficiência. A carga emocional presente na publicidade dos produtos - o prazer e o gozo imediato, ancorados na felicidade e na busca pelo conforto psíquico, a ideia de abundância - é um efeito que impulsiona o consumo. (Lipovetsky 1996) reflete que viver bem é ter um estilo de vida boa, pertencer a grupos, é conectar o material ao bem-estar, é estar ligado ao que ele chama de "frenesi" consumista e ser sensível ao sofrimento.

A propaganda vende ideias e a publicidade, produtos. O que há de comum entre as duas é o desejo de vender alguma coisa a alguém e, para tal, oferecer um benefício implícito na mensagem que produzem. Uma vende o candidato (ideia); a outra, um produto/mercadoria (valor). Em Propaganda e consciência popular (Chomsky 2003), podemos entender que a propaganda é um ato sobre a mente individual, sobre grupos com características comuns e que têm por objetivo a mudança de atitude.

Em se tratando de marketing, (Phillip Kotler 2010) - em um de seus mais 
Da propaganda à "publicidade" política: a ideia de consumo e descarte na campanha eleitoral de Haddad

de Diógenes José Pasqualini

recentes trabalhos, Marketing 3.0- busca nova definição, amparada pela American Marketing Association (2008), que diz: "Marketing é a atividade, conjunto de instituições e processos para criar, comunicar, oferecer e trocar ofertas que tenham valor para consumidores, clientes, parceiros e para a sociedade como um todo." (KOTLER 2010:23).

Se estamos lidando com três conceitos distintos - a propaganda, que comunica ideias, a publicidade, que vende produtos, e o marketing, como "atividade" ou "instituição" agregadora dos processos de "valor" -, podemos sustentar a hipótese de que, estrategicamente, o marketing político, assim como os partidos, está deixando de "vender" apenas ideias, ou seja, deixou de lado algumas bandeiras de luta de classe para se aliar às estratégias de consumo e potencializar sua comunicação de acordo com a tendência simbólica de consumo que o mercado exige.

(McLuhan 1974) antecipou este olhar para a massificação promovida pelo marketing de hoje, sintetizada na frase "satisfação garantida...", quando disse que "a pressão contínua é a de criar anúncios cada vez mais à imagem dos motivos e desejos do público. A importância do produto é inversamente proporcional ao aumento de participação do público". (MCLUHAN:255).

(Dominique Quessada 2003), em O poder da publicidade na sociedade consumida pelas marcas: como a globalização impõe produtos, sonhos e ilusões, também separa bem os conceitos ligados a publicidade e propaganda. Ele diz que a publicidade, diferentemente da propaganda, não troca ideias, não fomenta discussões e não faz pensar. Um de seus principais argumentos é que ele está na comunicação e tem papel específico, que é despertar o desejo de adoração às marcas e, assim, vincular grupos. (Quessada 2003) nos fornece pista muito interessante ao que sce busca sustentar aqui, em se tratando de aproximação dos discursos ideológicos da propaganda política com a publicidade. Está ligada à noção de limpeza que se contrapõe ao discurso político.

"A limpeza enunciada pelo discurso publicitário designa assim, por diferença, o discurso e a ação políticos como lugares da sujeira. Sendo o discurso que limpa, a publicidade se "posiciona" por diferença como um recurso possível contra o discurso político, que seria o discurso que suja". (QUESSADA 2003:74).

(Lipovetsky 1996) amplia este entendimento discursivo de que o marketing e a propaganda política "tomam emprestada" a estratégia da publicidade ao produzir sonhos, o descarte e a tolerância. Ele pondera que todo este excesso de sentido acaba colocando 
Da propaganda à "publicidade" política: a ideia de consumo e descarte na campanha eleitoral de Haddad

de Diógenes José Pasqualini

em risco as instituições democráticas. Argumenta também que o marketing político torna vulgar todo o cenário de poder ao relacionar consumo, sonhos e individualização.

[...] o marketing político faz correspondência à entrada das sociedades democráticas na era do consumo e moda: são valores implícitos em sua ordem; o hedonismo, o ócio, o jogo, a personalidade, o psicologismo, a cordialidade, a simplicidade, o humor que o tem impulsionado à reestruturação da ação política. (LIPOVETSKY1996:231).

\section{POSICIONAR O NOVO: OS CASOS FORD E HADDAD}

Duas coisas devem ser consideradas e guiam os posicionamentos "Viva o novo" e "O homem novo para o tempo novo". A primeira diz respeito aos valores de significação e à cultura ligada ao consumo, e a segunda, à condição de "verdade" que os slogans carregam. Slogan, na definição de (Oliver Reboul 1975), é “fórmula concisa e marcante, facilmente repetível, polêmica e frequentemente anônima, destinada a fazer agir as massas tanto pelo seu estilo quanto pelo elemento de autojustificação [...]" (REBOUL1975:39).

Há seis anos, quando a Ford lançou a campanha publicitária com o slogan de posicionamento "Viva o novo", ela propunha a substituição de um produto velho por modelo mais moderno de automóvel. Há muitos anos que o mercado de veículos, principalmente, propunha a renovação da frota brasileira, considerada em grande parte ultrapassada. Assim, a publicidade assume o discurso martelado há muito tempo e já retido na memória do consumidor da necessidade de os carros mais antigos deixarem as ruas. Esta 'ação de ordem' facilita o entendimento de uma necessidade inconteste, pois leva a crer em algo que parece extremamente pertinente.

Nos comerciais, chama a atenção o modo como as ideias vão sugerindo algumas atitudes em relação ao novo e fazem alusão ao desejo de mudar o mundo "para melhor". A retórica textual coloca o consumidor diante de argumentos "plausíveis" e aparentemente isentos de quaisquer ideologias, porque indústria, setor automotivo e autoridades políticas já haviam repetido diversas vezes que a frota brasileira era velha. Até o ex-presidente Collor tinha dito que os carros nacionais eram "verdadeiras carroças".

O código do novo nas sociedades contemporâneas é particularmente inseparável do avanço da igualdade de condições e da reivindicação individualista. Quanto mais os indivíduos se fecham em si mesmos, mais se põem à margem, mais aumenta o gosto 
Da propaganda à "publicidade" política: a ideia de consumo e descarte na campanha eleitoral de Haddad

de Diógenes José Pasqualini

pela abertura às novidades. $O$ Valor do novo corre paralelo à chamada demanda da personalidade e da autonomia privada. (LIPOVETSKY 1996:207).

A metáfora do novo é resultado de todo o entendimento cognitivo, em oposição velho x novo, associado a uma marca que fabrica carros. Os filmes mostram imagens que sugerem pessoas felizes, atitude, diferenciação, família, filhos, poder de compra, sucesso, vencedores, crença e consumo. Valores que, segundo Lipovetsky, são necessários para a sobrevivência das marcas, caso elas desejem ter forte poder de penetração. Também a substituição, em que o novo é superior ao velho, conforme este mesmo autor, produz uma ideia que remete ao progresso, à ciência e à competência, consagrando, assim, o individualismo da sociedade de consumo. A mensagem do comercial "Viva o Novo" vai nesta direção.

\begin{abstract}
"O novo incomoda. Por quê? Porque desafia! Mas queira ou não, o novo sempre vem, e para nossa felicidade, o novo geralmente vence. Quando o novo vence, a máquina do mundo gira melhor. Novos projetos deixam as tristezas numa agenda que não se abre mais. Novas crenças surgem para nos dar as mãos. Novos passos exigem de nós coragem. O novo é belo porque nos muda, nos leva a novas estações. O novo nos torna pessoas melhores, porque nos torna novas pessoas. $O$ novo é lindo! Assim como os sonhos, o novo não envelhece. Na Ford acreditamos que uma atitude inovadora pode mudar o mundo. Ford viva o novo". (online).
\end{abstract}

Um ano depois, nova campanha promove a reflexão do "Novo" contrapondo-se ao conformismo. Os filmes "pensar o novo" contextualizam ironia/humor ao exibir personagens em situações vexatórias. Os comerciais mostram um homem e uma mulher conformados em ter seus sonhos não realizados ou adaptados, marcados pela frase: “tudo bem”. O descrito aqui inclui a personagem Rosa.

Off-Rosa queria casar na primavera, mas aceitou casar no outono.

Personagem - Tudo bem.

Off- Rosa queria lua de mel na praia, mas se contentou com a cidade.

Personagem - Tudo bem.

Off-Rosa queria morar no oitavo andar, mas ficou feliz com o sétimo.

Personagem - Tudo bem.

Off-Rosa queria passear no zoológico, mas aceitou passear num parquinho.

Personagem - Tudo bem.

Off- Rosa! Chega de "tudo bem", você já pode ser exigente, chegou o novo Fiesta, novo interior, design totalmente novo. Melhor, só sendo seu. (online).

\title{
3. HADDAD - "O HOMEM NOVO"
}

Os programas de televisão do Partido dos Trabalhadores para Fernando Haddad 
Da propaganda à "publicidade" política: a ideia de consumo e descarte na campanha eleitoral de Haddad

de Diógenes José Pasqualini

associam as ideias de tempo e novo. Paradoxalmente, "ganhar e perder" tempo, noção capitalista de que tempo é dinheiro, aparece como argumento central em que o tempo passa a se relacionar com a economia, como discussão predominante que aparece na maior parte do texto de apresentação do candidato no primeiro programa de televisão.

[...] São Paulo acelerou o progresso do Brasil. Fez nosso país ganhar tempo na história. Mas, hoje, o paulistano é obrigado a perder muito tempo na vida. Perde tempo na fila do transporte, no trânsito, na fila da cirurgia, na fila do exame, na espera da creche, na espera da casa própria. O paulistano só não perde a esperança, porque sabe que isso pode mudar. (online).

Ao comunicar esperança e mudança, o slogan posicionamento "O homem novo para o tempo novo" aciona toda a cadeia de necessidades de mudança, de realizar trocas políticas, da construção de "uma nova São Paulo", de fazer mais em menos tempo, de ideias inovadoras, sob a noção de mudança de comando.

Se o slogan carrega a cadeia sígnica publicitária do novo, o formato comercial segue a mesma linha. Haddad se apresentou ao eleitor na televisão em quadro que remete aos comerciais da Nextel, em que o personagem fala em primeira pessoa, caminha livremente pelas ruas da cidade enquanto a câmera faz os movimentos de plano e contraplano, acompanhando o caminhar do personagem. O texto de Haddad pelas ruas de São Paulo:

"Nasci, cresci e vivo em São Paulo. Sinto muito orgulho disso. Essa é uma das cidades mais incríveis do mundo. Uma cidade que cresceu para todos os lados. Agora, é a hora de ela crescer para todos os seus filhos..." (online).

O da Nextel (surfista) em uma estrada:

“A princípio eu sou surfista, skatista, músico... vagabundo. Pelo menos é o que diziam. Há três anos eu fiz uma das maiores empresas de softwares do Brasil em oito países da América Latina e hoje eu viajo o mundo para surfar, para trabalhar também, porque não tem hora. Essa é minha vida, esse é meu clube”. (online).

Essa forma de construir o personagem para os filmes exemplifica a combinação ideológica que a publicidade espelha nos dois casos, do jovem moderno, que é livre para caminhar pelas ruas e ter atitudes de escolha. De expressar olhando nos olhos, falando diretamente às pessoas. $\mathrm{O}$ formato evidencia como velhas e ultrapassadas as produções do político que aparecia em estúdios, frio, com texto pronto e distante do 
Da propaganda à "publicidade" política: a ideia de consumo e descarte na campanha eleitoral de Haddad

de Diógenes José Pasqualini

cidadão.

A publicidade personaliza a marca e tem como principal papel remeter à mercadoria. Produzir necessidades para depois oferecer alguma coisa, benefício ou vantagem; como salienta Lipovetsky, mexe com os estímulos e alimenta um desejo já existente. No caso do discurso de Haddad em seu primeiro programa, a estratégia de explorar o bem-estar dos paulistanos relacionando o tempo e o sofrimento no trânsito ou no transporte coletivo foi umas das principais atrações. A uniformização dos gostos e desejos estruturou o que o paulistano já tinha não só em mente, mas que faz parte do seu dia a dia em se tratando da mobilidade urbana.

\section{CONCLUSÃO}

O que se conclui neste trabalho é que o marketing político também está buscando estabelecer no consumo uma relação de estímulo à venda eleitoral ao associar partidos a "marcas", fidelizar segmentos, empreender megaproduções nas campanhas políticas, agregar cada vez mais partidos às fusões e coligações em blocos e se distanciar das ideologias, da solução de grandes problemas. Não à toa, a superficialidade dos discursos publicitários não consegue fazer com que o eleitor reflita sobre os problemas de sua cidade, pois a propaganda entrega e sugere todas as soluções. Esta ruptura é um dos sintomas que favorecem o crescente aumento pelo desinteresse do eleitor pelo político, pelas eleições e partidos, como já nos foi sublinhado por (Lipovetsky 2007):

Um número crescente de pessoas considera que os políticos não têm palavra e estão interessados apenas em sua eleição: cada vez mais a classe política é posta em dúvida, considerada desonesta, incapaz de resolver os problemas fundamentais da sociedade. (LIPOVETSKY 2007:321).

Por esta lógica, o marketing político, assim como o marketing de produtos, colhe os discursos que são semeados pelos candidatos e transforma estes candidatos em mercadoria. A propaganda molda em linguagem o desejo de consumir quando percebe “o lugar" em que o sentido estrutura um desejo presente. Não é à toa que projetos de candidaturas vão se estruturando durante o desenrolar da campanha à espera de algum discurso que possa balizar algo que desperte a atenção do eleitor consumidor - seja a habitação, mobilidade urbana, saúde, transporte, meio ambiente ou qualquer outro que 
Da propaganda à "publicidade" política: a ideia de consumo e descarte na campanha eleitoral de Haddad

de Diógenes José Pasqualini

forneça algo "novo" que possa ser rapidamente consumido pelas massas.

No caso dos posicionamentos das campanhas da Ford e Haddad, há o entendimento de que uma ideia "nova" só pode ser viável, em se tratando de discurso, se ela estiver presente na mente das pessoas, se estiver consagrada no meio ao aproveitar todo o potencial dos signos já descritos aqui. Tanto a publicidade quanto a propaganda política, nos dois casos, relacionaram motivação e recompensa, escolha de alguma coisa moderna, diferente, sistema de valores que busca agregar pessoas ao prestígio, que explora a razão e a busca por uma verdade unificadora a partir dos padrões mais atuais do consumo.

Temos nestas campanhas dois casos de valor: o financeiro e o de sentido. Ambos se relacionam à troca, substituição, ao desatualizado, corroído pelo tempo e que necessita urgentemente ser substituído por algo novo. Esses valores são levados ao extremo simbólico ao juntar consumo, ideologia, política partidária e agregar Ford e Haddad ao conceito de produto, à ideia de serviço ao consumidor final. O "novo", comum às estratégias, é o que estrutura, é a espinha dorsal que permite abrir nosso canal perceptivo ao sentido das campanhas.

No caso da campanha de Haddad, há ainda a ressonância da participação e apoio político do ex-presidente Lula e toda a rede simbólica e de sentido que se liga a seu nome, ao entendimento de mito, glória, arquétipos e a toda ação retórica impregnada em seus discursos. E consegue agradar a tanta gente. Terry Eagleton (1997), ao citar Foucault em seu trabalho Ideologia: uma Introdução, resume bem esta questão ao dizer que "o que interessa não é tanto o que é dito, mas quem o diz e para que propósitos" (EAGLETON 1997:103).

Todos esses códigos de sentido são os ampliadores de entendimento e facilitam a escolha do eleitor, posicionando-o em uma zona de conforto que vai ao encontro da nova sociedade que se forma e que busca o bem-estar, a consagração e a glorificação dos que são bem sucedidos, daquele que nasceu pobre e superou todos os obstáculos, da qualidade de vida, das tecnologias e da relação das coisas novas com a vida moderna e a felicidade.

\section{REFERÊNCIAS BIBLIOGRÁFICAS}

CHOMSKY, N. Propaganda e consciência popular. Tradução de Désirée Motta Roth. 
Da propaganda à "publicidade" política: a ideia de consumo e descarte na campanha eleitoral de Haddad

de Diógenes José Pasqualini

Bauru, SP: Edusc, 2003.

EAGLETON, T. Ideologia: uma Introdução. Tradução de Silvana Vieira e Luís Carlos Borges. São Paulo: Editora da Universidade Estadual Paulista: Editora Boitempo, 1997.

FOUCAULT, M. A ordem do discurso. Tradução de Laura Fraga de Almeida Sampaio. São Paulo: Edições Loyola, 2001.

$\begin{array}{lllllll}\text { Campanha } & \text { Ford } & \text { Viva } & \text { o } & \text { novo } & - & \text { Disponível }\end{array}$ http://www.youtube.com/watch?v=Wv7rSFbqfmI - Acesso em 14/11/2012

$\begin{array}{llllll}\text { Comercial } & \text { Nextel } & \text { Surfista } & - & \text { Disponível }\end{array}$ http://www.youtube.com/watch?v=1SN_SLLwPvg - Acesso em 18/11/2012

Comercial Rosa - Disponível em: http://br.youtube.com/watch?v=g7AUb7j_C4Y acesso em 14/11/2012.

KOTLER, P, KARTAJAYA, H. e SETIAWAN, I. Marketing 3.0. Tradução de Ana Beatriz Rodrigues. 4.a tiragem. São Paulo: Campus Elsevier, 2010.

LIPOVETSKY, G. A felicidade paradoxal: ensaio sobre a sociedade de hiperconsumo. Tradução de Maria Machado, 2ª . reimpressão. São Paulo: Companhia das Letras, 2007.

El imperio de lo efímero: La moda y su destino en las sociedades modernas. Traducción de Felipe Hernández y Carmen López. 5.a Edición. Barcelona, Espanha: Editorial Anagrama, 1996.

LIPOVETSKY, G. \& ROUX, E. O luxo eterno: da idade do sagrado ao tempo das marcas. Tradução de Maria Lúcia Machado. São Paulo: Companhia das Letras, 2005 .

MACLUHAN, M. Os meios de comunicação como extensões do homem. Tradução de Décio Pignatari. Editora Cultrix: São Paulo, 1974.

Primeiro Programa Eleitoral de Fernando Haddad - Disponível em http://www.youtube.com/watch?v=KVonaLjOPoA - Acesso em 10/11/201

QUESSADA, D. O poder da publicidade na sociedade consumida pelas marcas: como a globalização impõe produtos, sonhos e ilusões. Tradução: Joana Angélica D’avila Melo. São Paulo: Futura, 2003.

REBOUL, O. O Slogan. tradução de Ignácio Assis Silva. São Paulo: Cultrix, 1975.

Artigo submetido: 10/09/2013 
Da propaganda à "publicidade" política: a ideia de consumo e descarte na campanha eleitoral de Haddad

de Diógenes José Pasqualini

Artigo aprovado: 13/11/2013 